\title{
ĢEOGRĀFISKĀS MOBILITĀTES IEZIMMES RĪGAS AGLOMERĀCIJĀ: IEKŠĒJĀS UN ĀRĒJĀS ZONAS SALĪDZINĀJUMS
}

\section{Jānis Krūmiṇš}

LU G̣eogrāfijas un Zemes zinātṇu fakultāte, e-pasts: kruminsjanis3@gmail.com

\begin{abstract}
Anotācija. Pētījuma mērķis ir izvērtēt pastāvīgās iekšzemes migrācijas iezīmes Rīgas aglomerācijā un skaidrot (1), vai Rīgas tuvums, kā arī sociālekonomiskās un sociāldemogrāfiskās atškirības starp zonām ietekmē pastāvīgās iekšzemes migrācijas plūsmu apjomus, (2), vai tas veido atškirīgas iedzīvotāju sastāva mainības tendences (3), vai pastāv atšķirības mobilitātes potenciāla ziṇā. Lai to paveiktu, tika analizēti sekundārie dati no dažādām institūcijām un G̣ZZF Cilvēka ǵeogrāfijas katedras anketēšanas rezultāti.
\end{abstract}

Atslēgas vārdi: iekšzemes migrācija, Rīgas aglomerācija, suburbanizācija.

\section{Ievads}

Iedzīvotāju ǵeogrāfiskā mobilitāte ir cieši saistīta ar urbanizāciju, kas attīstās dažādu sociālekonomisku, demogrāfisku un politisku procesu ietekmē. Tā nodrošina ne tikai darbaspēka kustību, bet arī ietekmē vietu, reǵionu un apdzīvojuma telpisko struktūru (Lewis 1988). Latvijā, tāpat kā citās Centrāleiropas un Austrumeiropas valstīs raksturīga lielo pilsētreǵionu attīstība un saiknes pastiprināšanās ar apkārtējām teritorijām (Sykora, Cermak 1998; Tammaru et al. 2004; Leetmaa et al. 2009; Szabo 
et al. 2014; u.c.). Latvijā ir veikta virkne pētījumu par iedzīvotāju ǵeogrāfisko mobilitāti valstī kopumā (Eglīte u.c. 1997; Bauls, Krišjāne 2000; Krišjāne, Bauls 2007; u.c.), mobilitātes lomu Rīgas aglomerācijā (Bērziņš 2011; Krišjāne et al. 2012), bet mazāk analizēti procesi dažādās Rīgas ietekmes zonās (Krišjāne, Bērziṇš 2009). Tāpēc ir svarīgi analizēt migrācijas procesus un svārstmigrācijas iezīmes un atšḳirības tieši dažādās aglomerācijas teritorijās.

Latvijai raksturīgās iekšzemes migrācijas plūsmas ir vērstas no valsts attālākiem reǵioniem uz tās centrālo daḷu - Rīgu, Pierīgu un Rīgas aglomerāciju. 2012. gadā aglomerācijas platība pēc tās robežu precizēšanas bija 7297,6 km² jeb 11,3\% no Latvijas kopējās platības (RD PAD 2012), bet šajā pašā gadā tās teritorijā dzīvoja 1168453 iedzīvotāji jeb 58\% no kopējā Latvijas iedzīvotāju skaita (CSP 2013). Tādējādi šai teritorijai ir raksturīgs izteikti augsts iedzīvotāju blīvums, sociālo un ražošanas iespēju paaugstināta koncentrēšanās, kas piesaista Latvijas perifērijās dzīvojošos. Tomēr Rīgas aglomerācija nav homogēna, un tai pastāv iekšējā un ārējā zona. Galvenokārt tieši attālums no aglomerācijas centra - Rīgas pilsētas, nosaka to, ka pastāv atškirīibas abu zonu pašvaldību sociāldemogrāfiskajos un sociālekonomiskajos rādītājos. Piemēram, ja iekšèjās zonas novados iedzīvotāju skaits no 2000. līdz 2015. gadam ir audzis vidēji par $12 \%$, tad ārējās zonas novados tas ir samazinājies par 13,1\% (CSP 2016).

\section{Materiāli un metodes}

Šajā pētījumā izmantoti sekundārie dati no LR Centrālās statistikas pārvaldes un Valsts reǵionālās attīstības aǵentūras, lai attēlotu un analizētu sociālekonomiskās atšķirības starp aglomerācijas zonām. Tāpat CSP dati izmantoti arī iekšzemes migrācijas plūsmu analīzē.

LU ĢZZF Cilvēka ǵeogrāfijas katedras anketēšana tika veikta 2014. gadā ārējā zonā (n=176) un iekšējā zonā (n=570). Iegūtie dati izmantoti, lai skaidrotu respondentu dzīvošanas ilgumu pašreizējā dzīvesvietā, kā arī potenciālu mainīt dzīvesvietu turpmāk.

\section{Rezultāti un intepretācija}

Rīgas aglomerācijas zonu neviendabību uzskatāmi parāda teritorijas attīstības indekss, ko veido dažādi sociālekonomiski un sociāldemogrāfiski rādītāji, piemēram, bezdarba līmenis, iedzīvotāju skaita pārmaiṇas pēdējo desmit gadu laikā, iedzīvotāju ienākuma nodoklis un demogrāfiskās slodzes līmenis. Salīdzinot ārējās un iekšèjās zonas novadus, bezdarba līmenis iekšèjā zonā ir zemāks (3,5\% pret 5\%), kāar ar̄ iedzīvotāju ienākuma nodokḷa vidējās iemaksas pašvaldības budžetā lielākas (676 pret 482 EUR uz iedzīvotāju) (VRAA 2015).

Aplūkojot teritorijas attīstības indeksu vērtību atškirības pašvaldībās 2014. gadā (1. attēls), redzams, ka augstāko vērtību koncentrācija vērojama iekšējā zonā. Būtībā no 12 attīstītākajām pašvaldībām Latvijā 11 atrodas Rīgas aglomerācijas iekšējā zonā. Iedzīvotāju skaita samazinājums ir galvenais iemesls tam, kāpēc septiniem ārējās zonas novadiem raksturīgi negatīvi attīstības rādītāji. Zemākie no tiem ir Jelgavas $(-0,2)$, Vecumnieku (-0,13), Skrīveru $(-0,116)$ novados $(0,113)$. 
Aglomerācijas centrs, Rīgas pilsēta sevī koncentrē funkcionālās, ražošanas u.c. veida iespējas, kas padara tam tuvos areālus īpaši pievilcīgus. Pirmkārt, attālums līdz Rīgas centram variē 15-45 minūšu intervālā piekḷuvei ar autotransportu (RD PAD 2012), otrkārt, piepilsētas vide ir pievilcīgāka nekā urbānā. Tomēr pastāv arī pretējs efekts - šīm pašvaldībām ir augsti standarti, kas atainojas nekustamo īpašumu cenās un zemes nodokḷ̆os. Pievilcīgā vide izraisa iedzīvotāju sastāva atjaunošanos iekšējā zonā, kā rezultātā vērojama pirmsdarbspējas un darbspējas vecuma iedzīvotāju paaugstināta koncentrēšanās. Šīs abas vecuma grupas kopā norāda uz jauno ǵimeņu klātesamību.

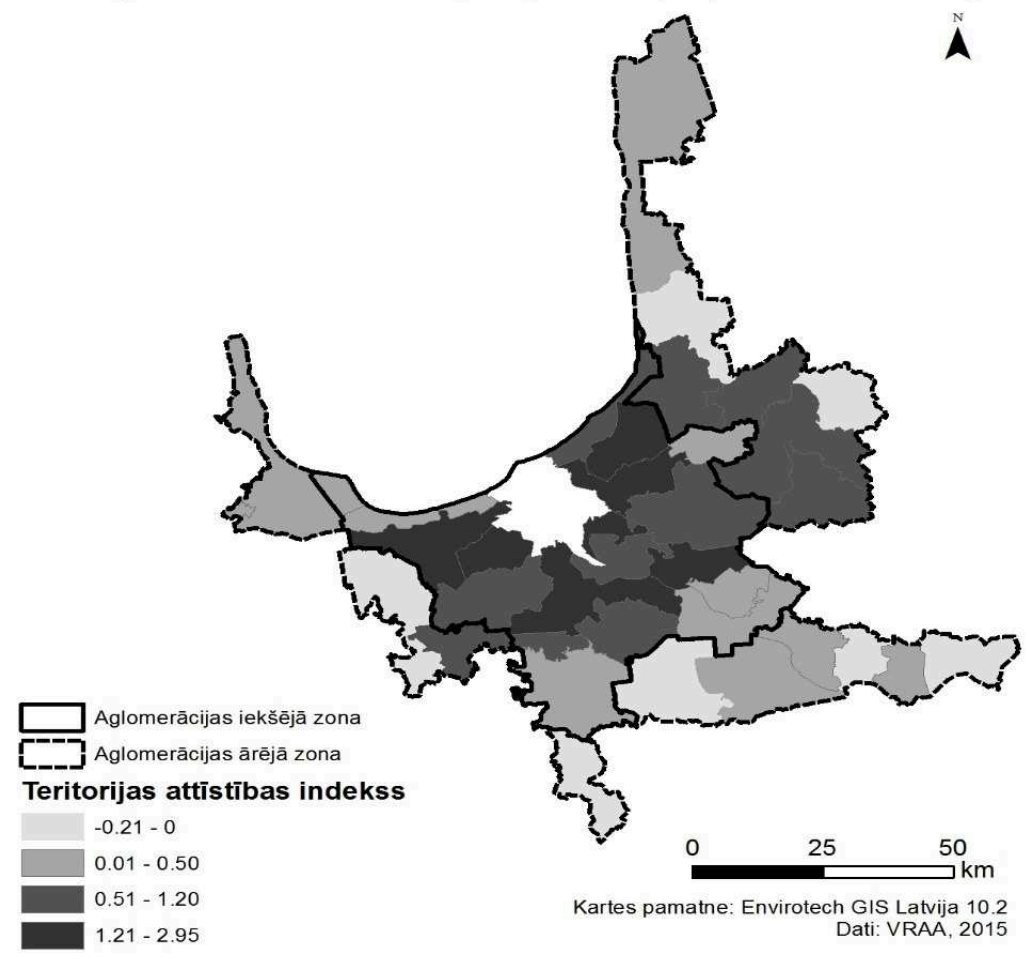

1. attēls. Teritorijas attīstības indekss Rīgas aglomerācijas pilsētās un novados 2014. gadā (izveidojis autors, izmantojot VRAA 2015)

Veicot aprēķinus par dažādām vecuma grupām un iedalot tās pēc geeogrāfiskā novietojuma aglomerācijā, atsevišķi ne pirmsdarbspējas, ne darbspējas dati neuzrādīja izteiktas tendences tam, lai varētu apstiprināt iepriekš teikto, tomēr, summējot abu grupu īpatsvaru, tika novērots, ka aglomerācijā (un Latvijā kopumā) vislielākais pirms un darbspējas vecuma ḷaužu kopējais īpatsvars ir 7 iekšêjās zonas novados, no kuriem lielākie - Mārupes (88,8\%), Garkalnes (86,3\%), Ādažu (86,2\%) novados. No ārējās zonas novadiem lielākais rādītājs ir Ozolnieku novadam - 82,7\% (CSP 2015).

Pilsētas tuvums, pievilcīgums veido arī iepriekšminētos augstos ekonomiskos standartus, kas padara dzīvesvietu suburbānajos areālos grūti saglabājamu. Rezultātā palielinās ǵeogrāfiskās mobilitātes intensitāte. Apkopojot datus par to iekšzemes migrācijas plūsmām no Rīgas aglomerācijas novadiem uz Rīgu laika posmā no 2011. līdz 2013. gadam, pastāv atšķirības starp iekšējās un ārējās zonas novadiem. 
Būtībā 15 novadi ar lielāko migrācijas plūsmu apjomu uz Rīgu atrodas tieši aglomerācijas iekšêjā zonā. Vislielākās plūsmas uz Rīgu šajā laika posmā raksturīgas Garkalnes (41 aizbraucējs uz 1000 iedzīvotājiem vidēji gadā), Carnikavas (35), Mārupes (31) novados. Ar sešpadsmito augstāko rādītāju izceḷas Sējas novads (14), kas ir augstākais starp ārējās zonas un pārējiem Latvijas novadiem (CSP 2014).

Gandrīz identiska situācija vērojama datos par iekšzemes migrācijas plūsmām no Rīgas uz tās aglomerācijas novadiem. Būtībā tie paši novadi ar lielākajiem rādītājiem vienā virzienā dominē arī otrā virzienā - Garkalnes novadam - 39 iedzīvotāji uz 1000, Carnikavai - 31 utt. Arī šeit augstākās 15 vērtības atrodamas starp iekšējās zonas novadiem, tomēr tās galvenokārt ir nedaudz mazākas nekā pretējā virzienā, veidojot novadiem negatīvu bilanci attiecībā pret Rīgu. Interesanti, ka iepriekš veiktā pētījumā, šādu analīzi izvēršot laika posmā no 2011. līdz 2012. gadam, iekšējās zonas novadiem galvenokārt bija pozitīva bilance ar Rīgu (Krūmiņš 2014).

Salīdzinot iekšējo un ārējo zonu pēc nodzīvotā laika dzīvesvietā, vadoties pēc 2014. gada anketēšanas datiem, tika konstatēts, ka nodzīvotā laika ilguma īpatsvaram konkrētajā teritorijā ir tendence augt, attālinoties no aglomerācijas centra. Ja iedalām datus 2 lielās grupās - tajos, kas dzīvo ilgāk par 10 gadiem (kopš dzimšanas arī tiek skaitīts šeit, jo jaunākie aptaujātie bija sasnieguši vismaz 16 gadu vecumu), un tajos, kas dzīvo mazāk par 10 gadiem savā pašreizējā dzīvesvietā, redzams, ka ārējā zonā neseno migrantu īpatsvars ir 31\%, bet iekšèjā - 42\%. Būtībā tas apstiprina faktu, ka iedzīvotāju sastāvs ir main̄̄gāks iekšējā zonā, un tur ir paaugstināta mobilitāte no Rīgas un valsts perifērijas, kamēr ārējā zonā pēcdarbspējas vecuma iedzīvotāju īpatsvars ir lielāks, kā arī mazāk mainīgs iedzīvotāju sastāvs, respektīvi, mazāki migrācijas apjomi.

\section{Pateicība}

Raksts izstrādāts ar Valsts pētījumu programmas pētnieciskā projekta Nr. 5.2.4. „Sabiedrības atjaunošana, samazinot depopulācijas riskus, veicinot tautas ataudzi un saiknes ar diasporu" atbalstu.

\section{Atsauces}

Bauls, A., Krišjāne, Z. (2000). Latvian Population Mobility in the Transition Period. Folia Geographica, X, 24-35.

Berziņ̌̌̌, M. (2011). Iedzīvotāju geeogrāfiskās mobilitātes loma suburbanizācijas norisēs Latvijā: doktora darbs. Rīga: LU G̣eogrāfijas un zemes zinātṇu fakultāte, Latvijas Universitāte.

CSP (2014). Centrālā statistikas pārvalde - Valsts iekšèjā iedzīvotāju ilgtermiṇa migrācija 2011.-2013.gadā Latvijas pilsētās un novados. MS Excel datubāze.

CSP (2016). Latvijas Republikas Centrālā statistikas pārvalde - Statistikas datubāzes. http://www.csb.gov.lv/ (3.02.2016)

Eglīte, P., Markausa, I. M., Ivbulis, B., Gņedovska, I. Zariņa, B.I. (1997). Demogrāfiskā situācija Latvijas laukos un iekšèjā migrācija 90.-to gadu pirmajā pusē. Apcerējumi par Latvijas iedzìvotājiem, 1-82. 
Krišjāne, Z., Bauls, A. (2007). Migrācijas plūsmu reǵionālās iezīmes Latvijā. Paaudžu nomaiņa un migrācija Latvijā. Stratēgiskās analīzes komisija. Zinātniski pētnieciskie raksti, 4(15), $130-143$.

Krišjāne, Z., Bērziņ̌s, M., Ivḷevs, A., Bauls, A. (2012). Who are the Typical Commuters in the Post-socialist Metropolis? The Case of Riga, Latvia. Cities, 29(5), 334-340.

Krūmiņš, J. (2014). G̣eogrāfiskās mobilitātes iezīmes Rīgas aglomerācijas nomalē. Mālpils novada piemērs: bakalaura darbs. Rīga: LU G̣eogrāfijas un zemes zinātṇu fakultāte, Latvijas Universitāte.

Leetmaa, K., Tammaru, T. Anniste, K. (2009). From Priority-Led to Market-Led Suburbanisation in a Post-Communist Metropolis. Tijdschrift voor Economische en Sociale Geographie. 100(4), 436-453.

Lewis, G. (1988). Counterurbanization and Social Chane in the Rural South Midlands. The East Midland Geographer, 11, 3-12.

RD PAD (2012). Rīgas domes Pilsētas attīstības departaments - Rīgas aglomerācijas robežu precizēšana. http://sus.lv/files/2012_Rigas_aglomeracijas_robezu_precizesana.pdf (17.11.2015)

Sykora, L., Cermak, D. (1998). City Growth and Migration Patterns in the Context of 'Communist' and 'Transistory' Periods in Prague's Urban Development. Espace, Population, Societes, 3, 405-416.

Szabo, T., Szabo, B., Kovacs, Z. (2014). Polycentric Urban Development in PostSocialist Context: the Case of the Budapest Metropolitan Region. Hungarian Geographical Bulletin. 63(3), 287-301.

Tammaru, T., Kulu, H., Kask, I. (2004). Urbanization, Suburbanization and Counter Urbanization in Estonia. Eurasian Geogaphy and Economics, 45, 159-176.

VRAA (2015). Valsts reǵionālā attīstības aǵentūra - Plānošanas reǵionu, republikas pilsētu un novadu attīstības pamatrādītāji 2014. gadā. http://www.vraa.gov.lv/lv/petnieciba/statistika/develop/ (3.02.2016)

\section{Summary}

The main aim of this research is to evaluate patterns of internal migration in the Rīga Metropolitan Area, and to 1) describe how the proximity of Rīga along with socio-economic and socio-demographical differences between zones affects migration flows, 2) to analyze if there are any tendencies regarding changes within composition of the population, and to 3) see if there are any changes between migration potentials and motivating factors to move between two zones.

After summarizing research data, it is possible to conclude that the municipalities of an internal zone, in comparison to the external zone, have: 1) higher internal migration flow amounts in both directions (to and from Rìga); 2) higher total share of pre-working and working age people $(81,3$ vs $78,5 \%)$; 3 ) lower percentages of inhabitants who are living in their current residence for at least 10 years (58 vs 69\%); 4) higher desire to change their place of residence in following years $(72,8$ vs $66,9 \%)$.

Such differences suggest that the internal zone has a more floating population composition and a higher potential for mobility. The proximity of Rīga makes the internal zone an attractive environment for new families with children; however, high economic standards (high taxes, real estate prices) characteristic to this area contribute to migration. 